\title{
Inferring Diversity and Evolution in Fish by Means of Integrative Molecular Cytogenetics
}

\author{
Roberto Ferreira Artoni, ${ }^{1}$ Jonathan Pena Castro, ${ }^{1}$ \\ Uedson Pereira Jacobina, ${ }^{2}$ Paulo Augusto Lima-Filho, ${ }^{3}$ \\ Gideão Wagner Werneck Félix da Costa, ${ }^{4}$ and Wagner Franco Molina ${ }^{4}$ \\ ${ }^{1}$ Departamento de Biologia Estrutural, Molecular e Genética, Universidade Estadual de Ponta Grossa, \\ 84030-900 Ponta Grossa, PR, Brazil \\ ${ }^{2}$ Departamento de Zoologia, Universidade Federal de Pernambuco, Cidade Universitária, 50670-420 Recife, PE, Brazil \\ ${ }^{3}$ Instituto Federal de Educação, Ciência e Tecnologia do Rio Grande do Norte, 59500-000 Macau, RN, Brazil \\ ${ }^{4}$ Departamento de Biologia Celular e Genética, Centro de Biociências, Universidade Federal do Rio Grande do Norte, \\ 59078-970 Natal, RN, Brazil
}

Correspondence should be addressed to Roberto Ferreira Artoni; rfartoni@gmail.com

Received 10 May 2015; Revised 20 July 2015; Accepted 22 July 2015

Academic Editor: Alexander Belyayev

Copyright (c) 2015 Roberto Ferreira Artoni et al. This is an open access article distributed under the Creative Commons Attribution License, which permits unrestricted use, distribution, and reproduction in any medium, provided the original work is properly cited.

Fish constitute a paraphyletic and profusely diversified group that has historically puzzled ichthyologists. Hard efforts are necessary to better understand this group, due to its extensive diversity. New species are often identified and it leads to questions about their phylogenetic aspects. Cytogenetics is becoming an important biodiversity-detection tool also used to measure biodiversity evolutionary aspects. Molecular cytogenetics by fluorescence in situ hybridization (FISH) allowed integrating quantitative and qualitative data from DNA sequences and their physical location in chromosomes and genomes. Although there is no intention on presenting a broader review, the current study presents some evidences on the need of integrating molecular cytogenetic data to other evolutionary biology tools to more precisely infer cryptic species detection, population structuring in marine environments, intra- and interspecific karyoevolutionary aspects of freshwater groups, evolutionary dynamics of marine fish chromosomes, and the origin and differentiation of sexual and B chromosomes. The new cytogenetic field, called cytogenomics, is spreading due to its capacity to give resolute answers to countless questions that cannot be answered by traditional methodologies. Indeed, the association between chromosomal markers and DNA sequencing as well as between biological diversity analysis methodologies and phylogenetics triggers the will to search for answers about fish evolutionary, taxonomic, and structural features.

\section{Introduction}

Investigating $50 \%$ of the total biodiversity is a hard and exciting task for most ichthyologists. Fish are represented by 32,900 species; more than 20,000 are marine and 8,000 are living in Neotropical continental waters [1,2].

Cytogenetics, which is the study of chromosomes, is becoming an important biodiversity-detection tool also used to measure biodiversity evolutionary aspects [3, 4]. Cytogenetics also enables the development of evolutionary, taxonomic, and phylogenetic inferences resulting from the support provided by the conservation of Neotropical fish species [5]. Firstly, this scientific field took steps towards describing and defining the chromosomal morphology of the species according to usual cytogenetic analysis methods such as the conventional staining. The first marks in the chromosome of fish were identified by classic chromosome techniques, C-banding, and the detection of nucleolar organizing regions (Ag-NORs); for review see [6]. The identification marks revealed much information about the evolutionary processes within this group such as chromosome rearrangements, structural and/or numeric polymorphisms, and sexual 
chromosome systems and variations associated with the geographic distribution of some species and/or populations $[4,7]$. Although these techniques have enabled good insights into the understanding of chromosome diversity in fish, the access to the genome was limited, mainly in many families that have quite stable conservative karyotypes and banding patterns, a fact that has hindered the detection of their most diverse genetic divergence levels [8].

The methodological advances on chromosome analyses drastically grew in the last decades; they showed refinement and more accurate resolution power, due to molecular cytogenetics by fluorescence in situ hybridization (FISH) [9]. Such technique strongly improved the transition from classic to molecular cytogenetics. It allowed integrating the quantitative and qualitative data from DNA sequences and their physical location in chromosomes and genomes [10]. The FISH technique enables identifying the DNA sequences in the studied cytological material (target DNA), no matter if they are chromosomes or interphase nuclei fixed on the surface of the slide.

Many changes in this technique have been adapted and improved in cytogenetics laboratories, due to advances in microscopy and bioinformatics. However, FISH principles and procedure steps (marking, hybridizing, and detecting) have remained the same. Its greater resolution power plays an important role in precisely featuring the chromosome structures of many fish species [11]. Different technique types, based on the herein referred methodology, such as genome in situ hybridization (GISH), in situ simultaneous location of different chromosome regions by Multicolor FISH (mFISH), and identification of specific regions by chromatin fiber extended (Fiber-FISH) or spectral karyotype (SKY), are known and applied to distinct means.

The mapping of repeating DNA has been the main use of the FISH applied to fish. Among these sequences, it is possible to highlight the chromosome locations of multigene families such as $18 \mathrm{~S}$ and $5 \mathrm{~S}$ ribosomal DNA, histones, telomeric and centromeric sequences, and transposable elements [11]. The isolation and application of specific satellite DNA probes have also been the routine method in intraspecific characterization as well as in the understanding of evolution sequences among related species [12]. These probes help detecting chromosomal homeologies by identifying syntenic groups kept or rearranged during karyotype divergence among analyzed species [13]. These studies aim to understand the structural nature and the likely origin of B or supernumerary chromosomes [14] and to draw the origin and evolution of sexual chromosomes [15] and their behavior in the meiotic cells [16].

FISH potentialities are highly broad. The technique enables the better grounding of hypotheses heading towards structural, taxonomic, population, and/or phylogenetic aspects. It happens along with the easiness and availability of prospecting probes through different strategies [17]. These data are crucial for understanding the chromosomal dynamics and evolution and how it may be linked to speciation processes and macroevolutionary events. Throughout the data presentation, the current study aims to assess the contributions provided by the herein described technique and to integrate fish genome.

\section{Cryptic Species Detection and Population Structuring in Marine Environments}

Marine biogeography studies the history of marine taxa geographic distribution and it aims to set endemism areas as well as broad global distribution patterns [18]. The combined action of certain parameters such as the pelagic larval period duration, the individual's power to disperse in adulthood, and the actions resulting from ocean currents have shaped the chromosomal diversity of species, although it is difficult to indicate one single determining factor of cladogenetic events.

There is an exuberant diversity of shapes and wide body size variety in the Perciformes order, which holds more than 10,000 species [19]. This morphological diversity contrasts with the high karyotype stability [20] found in most representatives of this order. They are acrocentric diploid and have fundamental number $2 n=48$ chromosomes, simple ribosomal sites, and little heterochromatin mostly concentrated in the pericentromeric regions [21]. However, the stronger chromosomal dynamism is shaped by pericentric inversions and, in smaller proportion, by centric fusions, just as it happens in some families, mainly in those that live in coral reefs [22]. These evidences enable discriminating populations in the Brazilian coast by classic banding [23], although such procedure is not always resolute.

Studies focused on population cytogenetics are incremented by the use of in situ hybridization. FISH was used to discriminate so far nondiagnosed cryptic karyotypes by conventional techniques. Indeed, its use detected different fishery stocks of the circumtropical species Caranx lugubris in São Pedro and in São Paulo Archipelagos $(1,100 \mathrm{Km}$ away from the Brazilian coast). Although they apparently present homogeneous karyotypes regarding chromosomal morphology, C-banding, and Ag-NORs, these morphotypes diverged on the frequency of $5 \mathrm{~S}$ ribosomal gene sites, thus corroborating the distinct morphological patterns. These data suggest that the possible contact among stocks from other oceanic regions may take place in these oceanic islands [24]. This same analytical approach also shows population fragmentation in Bathygobius soporator within the Northeast region of Brazil as well as revealing remarkable chromosomal differentiations among coastal populations and populations in Rocas Atoll, regions approximately $267 \mathrm{Km}$ geographically distant from each other, a fact that points towards new species in the area [25].

The use of available molecular phylogenies enables associating chromosomal patterns and preestablished topologies. It allows follow-ups in the history of these characters. The interaction among DNA sequences and chromosomes enables polarizing the chromosomal changes, identifying the consistency of phylogenetic signs or the possible homoplasies and evolutionary trends, and diversifying mechanisms in the group [26]. Drawing the history of these characters seems to be a big challenge in Perciformes, since the established chromosomal conservatism strongly features many families [21]. 


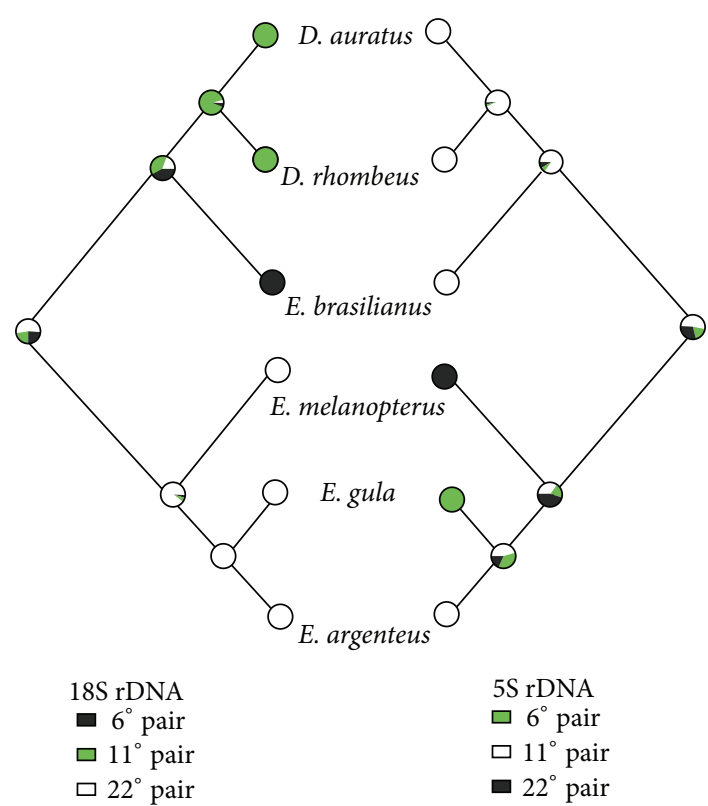

FIGURE 1: Reconstruction of ancestral characters of 18 S and 5S rDNA in six species from the Gerreidae family (Eucinostomus gula, Eucinostomus melanopterus, Eucinostomus argenteus, Diapterus auratus, Diapterus rhombeus, and Eugerres brasilianus), which was gotten by means of the Mesquite software using the MK-1 model. Phylogenetic hypothesis estimated by likelihood analysis based on mtDNA COI sequences.

Actually, this trend is found in the Gerreidaefamily, which shows most of its representatives with $2 n=48$ acrocentric chromosomes $[27,28]$. It is possible to identify the independent evolution of these genes in both genera, Diapterus and Eucinostomus (Figure 1), by crossing the history of the characters and the information from the $18 \mathrm{~S}$ and $5 \mathrm{~S}$ ribosomal genes. Whereas the $18 \mathrm{~S}$ rDNA sites present higher location variability in Diapterus [28], this same gene, in Eucinostomus, appeared to be quite conservative and located in the same pair of different species of this genus [27]. On the other hand, inverse pattern is found in $5 \mathrm{~S}$ rDNA sites, in which the loci are located in different pairs in representatives of the genus Eucinostomus, whereas, in Diapterus, this same genus appeared to be conservative in the analyzed species $[27,28]$.

\section{Intra- and Interspecific Karyoevolutionary Aspects of Freshwater Groups}

Freshwater fish offer extremely informative models to investigate geologic background and connectivity among basins during the identification of biogeographic processes [29]. The Neotropical region offers excellent opportunities to the study on diversification mechanisms among freshwater fish. The region holds the biggest biodiversity in the world due to complex ecological and historical processes that deal with isolation and specialization [30]. More than 1,000, out of the 8,000 estimated species, already have information about their karyotype and demonstrate great diversity in diploid values. It covers from $2 n=20$ chromosomes in Pterolebias longipinnis (Rivulidae) up to $2 n=134$ in catfish Corydoras aeneus [31].

Continental systems physical subdivisions are often effective in blocking gene flow. Such condition leads to species endemism in some regions [32], whereas, in others, despite demanding broad contribution, they are morphologically categorized as a single taxon. They show remarkable differences in the chromosomal number as well as showing morphology that highlights the occurrence of complexes of species $[4,33]$.

Hoplias malabaricus consists of seven karyomorphs. It provides an exceptional way to understand historical relations in different draining within the Neotropical region [4, 34]. Close relations are found among populations from adjacent basins that share the same karyomorph and they indicate the phylogenetic ancestry among these hydrographic basins. However, differences in the number of $18 \mathrm{~S}$ ribosomal sites point towards historical gene flow restrictions among these populations [35]. The mapping analysis of 5SHindIII satellite DNA is effective in characterizing allopatric populations of such species in DNA sequence mapping when there is no divergence between pairs carrying the $18 \mathrm{~S}$ rDNA. It shows clear interpopulation divergences that result from different evolutionary histories triggered by this basin's geological isolation [13].

The taxonomic relations in the Parodontidae family, which presents stable karyotypes, are the target of controversies [36]. Although the location of $18 \mathrm{~S}$ ribosomal genes appears to be discriminating between the genera Parodon and Apareiodon, the first genus possesses more conservative conditions. The first ones show more conservative conditions located in the terminal region of the long arm of one subtelocentric chromosome pair in all species studied thus far and in Parodon it reveals higher dynamism among the species [37]. The 5S rDNA sites appear to be more conservative in Parodontidae, found in pericentromeric position in a submetacentric pair similar in Anostomidae, sister family [38].

The mapping of $5 \mathrm{~S}$ rDNA enables discriminating sisterspecies such as Oligosarcus solitarius and $O$. argenteus (Characiformes). The complementary localization data, in $18 \mathrm{~S}$ rDNA sites, allow interpopulation differentiations in $O$. solitarius [39].

Briefly, for instance, the countless FISH applications through $18 \mathrm{~S}$ and $5 \mathrm{~S}$ ribosomal genes appear to be resolute in establishing phylogenetic relations in species discrimination as well as in understanding population historical relations in either freshwater or marine environments.

\section{Evolutionary Dynamics of Marine Fish Chromosomes}

Some fish groups, mostly in the Perciformes order, show a well-known low karyotypes dynamics [8]. Overall, such condition is due largely to biological and environmental characteristics of the marine biome. Species with high dispersive potential [23] and high population contingents [40] seem to be particularly refractory to chromosomal change fixations in their karyotypes. These conditions are particularly pronounced in marine species. The absence of geographic 


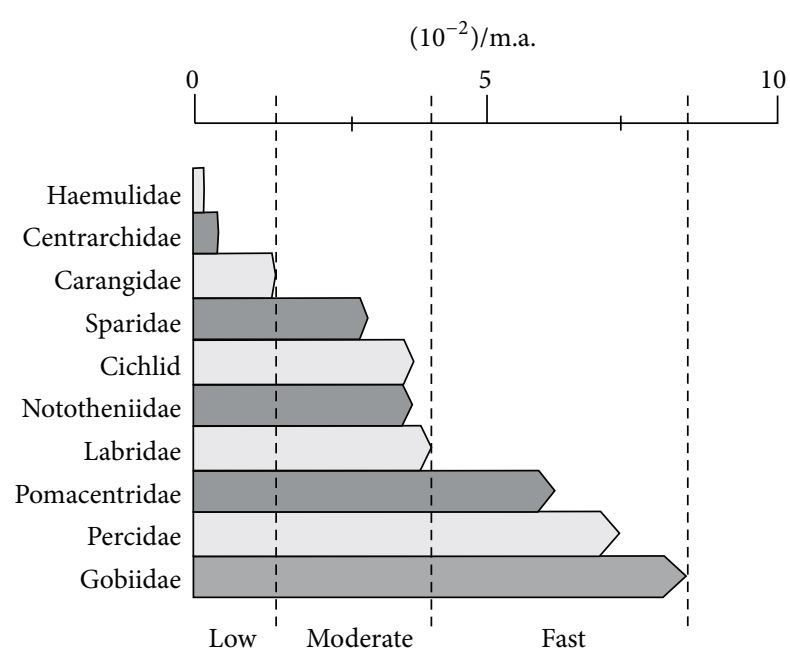

FIgURE 2: Karyotype diversification taxa in some Perciformes families (modified by Molina et al., 2014). Groups presenting low, moderate, and fast chromosomal divergence rates allow differentiated uses of FISH mapping in the analyses of their evolutionary dynamics.

barriers and the attention given to the other two conditions are more easily found.

Karyotype evolution rates in Perciformes can be classified in three diversification levels, that is, low, moderate, and high. Some families present bradytelic evolution, which is once more exemplified by taxa as low as $0.094 \times 10^{-2} / \mathrm{m}$.a. in Haemulidae. There is a second group, which holds families that present moderate karyotype evolution, horotelic, and in which Sparidae and Labridae show rates that, respectively, vary from $2.933 \times 10^{-2} / \mathrm{m}$.a. to $4.031 \times 10^{2} / \mathrm{m}$.a. There is one last group composed of families such as Pomacentridae and Gobiidae that present remarkable tachytelic evolution with rates that vary from $6.124 \times 10^{-2} /$ m.a. to $8.943 \times$ $10^{-2} / \mathrm{m}$.a. The karyotype evolution rate varies in the range of one hundred times (Figure 2). Perciformes constitute an exceptional evolutionary model for chromosomal studies [41].

It is possible to find some families of marine Perciformes such as Sciaenidae, Chaetodontidae, Gerreidae, and Lutjanidae [23, 27, 41, 42] among groups that show slow karyotype evolution. These groups present karyotype composed of $2 n=48$ acrocentric chromosomes and it is a plesiomorphic condition shared by Percomorpha [43]; thus it possibly reaches Acanthopterygii [41].

Entire families can share the same karyotype, but it is practically unchangeable under the sieve of classic cytogenetic analyses. As for Lutjanidae, the so far analyzed species often present common karyotype $(2 n=48$ acrocentric chromosomes). This is the same condition found, for instance, in Sciaenidae, Chaetodontidae, Haemulidae, and Gerreidae [44]. Such karyotypes share features such as symmetric chromosomes (small size difference among bigger and smaller karyotype elements), reduced heterochromatic regions, homogeneous heterochromatin [40], and single ribosomal sites (Ag-NORs) [21]. According to an evolutionary perspective, these chromosomal characters significantly hinder the establishment of intraspecific diversity indicators as well as of phylogenetic inferences among the species.

The Ag-NORs sites are effective cytotaxonomic loci in conservative karyotypes. Approximately 330 teleost species from 77 families distributed into 22 orders were already analyzed. NORs present single sites in $72 \%$ of the species; besides, they constitute notably diverse regions in comparison to other genes [45]. Thus, in some cases, rDNA may appear limited to identify exclusive differentiations in its positioning and frequency, mostly among species from families that present notable chromosomal conservatism and, therefore, low evolutionary dynamics [40,41].

Despite the fact that cytogenetic analyses provide more robust data, their exclusive use is quite limited and it just covers a short percentage (1.3\%) of teleost species [45]. The in situ DNA sequence mapping enables identifying high syntenic chromosomal conservatism among species from marine fish families [40]. It shows that it can be an extensive condition to have a broad spectrum in one single clade. On the other hand, in some cases, it also enables evidencing the occurrence of extensive evolutionary changes with regard to the dispersion of some repeating sequences, both coding or noncoding.

Multigene families are repeating sequences of coding DNA that belong to a family of related proteins coded by a set of similar genes. These families are formed by duplication events during evolution. The observed differences reflect the mutations that took place throughout time. Histone and ribosomal genes are found among these differences. Chromosomal rearrangements disperse the multigenic families through the genome, which may be followed by the physical mapping of its sequences. Generally, the multigene families present a considerable number of pseudogenes; thus they show similarities with functional genes in the same family, although they enable functionality due to the acquired mutations [46].

rRNA genes are among the better known multigene families in fish. In fact, the $18 \mathrm{~S}$ and $5 \mathrm{~S}$ ribosomal genes are the highlighted repeating sequences mostly found in fish chromosomal evolutionary studies [45].

The evolution of $5 \mathrm{~S}$ rDNA genes is progressively better understood [47]. The molecular variability observed for $5 \mathrm{~S}$ rDNA gene is due mainly to NTS regions (nontranscribe spacer regions). Retrotransposons and microsatellites also seem to be involved with the high dynamism of their sequences [48]. The $5 \mathrm{~S}$ rDNA is distributed into one or a few sites [46], among various fish groups. However, the physical mapping of these sequences by FISH in rare situations has revealed a massive dispersion in most of the chromosomes of some species. Such situations are observed in families with conservative evolutionary patterns such as Pomacanthidae [49] as well as in those with more dynamic patterns such as Gobiidae [25]. In this last family, the species Ctenogobius smaragdus, with $2 n=48$ chromosomes, exhibits $5 \mathrm{~S}$ hybridization marks in 42 chromosomes of the karyotype (Figure 3), and it suggests that not all these regions are active [50]. 


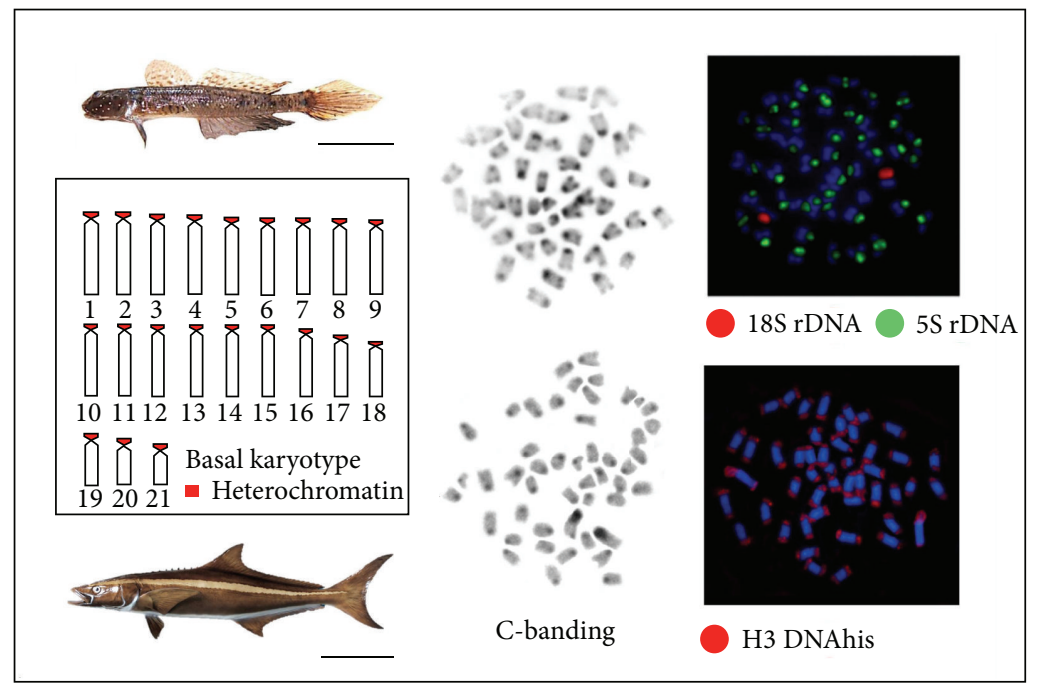

FIGURE 3: Basal karyotype pattern in the Perciformes and extensive dispersion events of sequences of the 5S DNAr multigenic families in Ctenogobius smaragdus (above) and of DNAhis $\mathrm{H} 3$ in Rachycentron canadum (below). Bar $=1$ and $10 \mathrm{~cm}$, respectively.

The complementary mapping of the $18 \mathrm{~S}$ and $5 \mathrm{~S}$ ribosomes enables the better and more efficient option of specific cytotaxonomic loci in some groups of species with high karyotype conservatism. As for Haemulidae, which is a group with genera that show low evolutionary dynamics (e.g., Haemulon, Pomadasys, and Conodon), the species share a uniform karyotype [40,51]. Species carrying symmetric karyotypes formed by acrocentric chromosomes with reduced heterochromatic content and, in general, with single ribosomal sites present limitations to identify interspecific diversification patterns by means of classic cytogenetic methods. Indeed, as for these cases, the combined use of mapping by applying the double FISH to $18 \mathrm{~S}$ and $5 \mathrm{~S}$ genes is particularly indicated. It enables analyzing these genes' genomic dynamics as well as identifying the interspecific diversity $[27,28]$.

With regard to other marine fish groups, the physical map of $\mathrm{H} 1, \mathrm{H} 2 \mathrm{~B}, \mathrm{H} 2 \mathrm{~A}$, and $\mathrm{H} 3$ histone genes shows interesting information about their evolution and it leads to insights into their dynamics in the species' karyotype $[25,50]$. These genes play a key role regarding changes in the chromatin structure, in cellular cycle progression, and in gene activity repression [52, 53]. Besides, little is known about their physical positioning in the chromosome of fish. The $\mathrm{H} 1$ multigenic family constitutes the histone class with the faster evolutionary rate, whose diversification, mainly by evolution in concert [54], has been questioned in favor of birth-anddeath evolution [55].

Cytogenetic analyses among populations and Bathygobius (Gobiidae) species, which is a group with high evolutionary dynamism, showed that $\mathrm{H} 1$ histone genes positioning and frequency are conserved with two sites kept in homologs chromosomes [25]. On the other hand, the H2B-H2A DNAhis and H3 DNAhis genes in Rachycentron canadum (Rachycentridae) presented the more diversified condition. Actually, this species of $\mathrm{H} 2 \mathrm{~B}-\mathrm{H} 2 \mathrm{~A}$ genes presented multiple sites distributed in up to 6 chromosome pairs in the karyotype, whereas $\mathrm{H} 3$ sequences (Figure 3 ) are surprisingly distributed throughout all the chromosome pairs [50]. These data suggest a diversification pattern that matches the birth-and-death evolutionary model. It is followed by the purifying selection found in $\mathrm{H} 2 \mathrm{~B}-\mathrm{H} 2 \mathrm{~A}$ histone genes as well as by the variation resulting from the evolution in concert, which involves $\mathrm{H} 3$ histone genes. These data reinforce the independent evolution of histone genes in this species. These genes appear to be colocated with many other repetitive DNA, microsatellites, $18 \mathrm{~S}$ and 5S rDNA, transposons, and retrotransposons [42]. Distribution analysis of H3 DNAhis site, in five Lutjanidae species, showed that these genes are found in a single site in most of species (Lutjanus analis, L. synagris, and $L$. alexandrei). However, they can be found in two loci (L. jocu) or extensively dispersed in 44 out of the 48 chromosomes in Ocyurus chrysurus [42]. This low diversification pattern, which is highlighted by significant changes in the dispersion of sequences, is associated with the participation of transposable elements in the species' karyotype [50].

Repetitive DNA represent approximately $50 \%$ of the eukaryote genomes. The accumulation of these repetitive sequences is responsible for the variation in the genome size in the eukaryotes. It points out their influence on DNA replication, recombination, and gene expression band on the differentiation of sexual and B chromosomes [56]. Besides, the repetitive DNA are also involved with chromosomal rearrangements such as deletions, duplications, inversions, and reciprocal translocations, thus providing karyotype diversification in many groups [57]. The physical mapping of these sequences in the chromosomes enables accessing countless aspects related to the origin and evolution of sexual and $B$ chromosomes $[58,59]$.

\section{The Origin and Differentiation of Sexual and B Chromosomes}

Another main element in the karyotype structure of fish regards the presence of sexual chromosomes. Fish, differently 
from birds and mammals, do not present sexual chromosomes on the basis of their phylogeny. Thus, this character independently and repeatedly emerged in the evolutionary history of this group. Some species present quite differentiated sexual chromosomes, although such occurrence is not frequent.

Sex chromosomes systems with female heterogametic $(\mathrm{ZZ/ZW})$ are found in some species in the genera Leporinus [60], Parodon [61], and Triportheus [62]. It is evident, in most of these cases, that sex chromosome differentiation was followed by the heterochromatinization process and by changes in the size of $\mathrm{W}$ chromosome. XX/XY systems were described in Pseudotocinclus tietensis (Loricariidae) and also in the genus Hoplias [63], respectively. In addition, simple systems (XY and ZW) may undergo rearrangements and originate multiple sexual systems. There is the case of multiple sex chromosomes with female heterogamety $\left(\mathrm{ZZ} / \mathrm{ZW}_{1} \mathrm{~W}_{2}\right)$ reported in Apareiodon affinis [64].

The systems with male heterogamety have the first records in Neotropical fish in the genera Hoplias, with multiple sex chromosomes such as $\mathrm{X}_{1} \mathrm{X}_{1} \mathrm{X}_{2} \mathrm{X}_{2} / \mathrm{X}_{1} \mathrm{X}_{2} \mathrm{Y}$ and $\mathrm{XX} / \mathrm{XY}_{1} \mathrm{Y}_{2}$ [65], and Eigenmannia, with a $\mathrm{X}_{1} \mathrm{X}_{1} \mathrm{X}_{2} \mathrm{X}_{2} / \mathrm{X}_{1} \mathrm{X}_{2} \mathrm{Y}$ system [66].

So far, the chromosomal location of these genes in most fish species is still an open issue, although sex-determining genes may occur even without the presence of morphologically differentiated sex chromosomes. On the other hand, consistent advances have been achieved in the detection of these sexual chromosomes as well as in the origin and differentiation processes, by applying the whole chromosome painting (WCP). Some examples well depict this situation either in simple or multiple systems. Within simple systems, it is possible to identify the genes differentiation discerning homologous segments among the allosomes, as it can be seen in species in the genus Triportheus [67]. In multiple systems, the origin of sex neochromosomes is evidenced by Robertsonian fusions, as it is seen in species in the genus Harttia [68]. Furthermore, the use of chromosome painting also helps solving issues of common and/or independent origin such as the case linked to the Erythrinidae family in which the multiple system $\mathrm{X}_{1} \mathrm{X}_{1} \mathrm{X}_{2} \mathrm{X}_{2} / \mathrm{X}_{1} \mathrm{X}_{2} \mathrm{Y}$ found in Hoplias malabaricus and Erythrinus erythrinus presented independent origins [59].

Using FISH to investigate sex chromosomes is also a way to determine the location of ribosomal genes related to heterogametic sex chromosomes differentiation. There is an example of it in the $\mathrm{W}$ chromosome from the $\mathrm{ZW}$ system in genus Triportheus [62] and from the XX/XY system in Hoplias [35]. Besides, it has been possible to detect the residual interstitial telomeric sequences (ITS) from the centric fusion process in the formation of the $\mathrm{XX} / \mathrm{XY}_{1} \mathrm{Y}_{2}$ multiple sexual chromosome system in Harttia carvalhoi [68]. Heterochromatization processes played an active role in the process of differentiating diverse sexual chromosome systems. The location of repetitive sequences over the sexual chromosomes helps elucidating differentiation processes due to the presence of Rex elements spread over the $\mathrm{W}$ chromosome in Semaprochilodus taeniurus [69] and the presence of microsatellites and different Rex in the $\mathrm{Z}$ and $\mathrm{W}$ chromosomes in Triportheus trifurcatus [15].

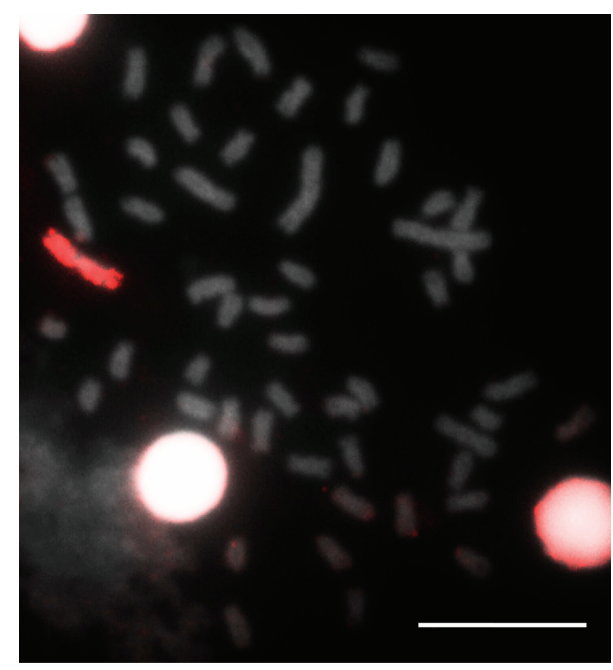

FIGURE 4: Astyanax scabripinnis metaphase chromosomes subjected to WCP with B chromosome probe amplified by DOP/PCR and marked by nick translation with streptavidin (red). Bar $=10 \mu \mathrm{m}$.

Another emblematic matter concerning the karyotype of fish regards the occurrence of $\mathrm{B}$ or supernumerary chromosomes, as it is observed in Apareiodon piracicabae and Paraligosarcus pintoi [70], Prochilodus lineatus and P. cearensis [71], Curimata modesta [72], Steindachnerina insculpta [73], Schizodon [74], among others. Those are additional chromosomes that do not recombine with those from the standard karyotype complement and follow their own evolutionary path [75]. Among fish, it is possible to highlight the complex of Astyanax scabripinnis species as the currently more studied model concerning supernumerary chromosomes (Figure 4) distribution, behavior, and origin (for review check [76]).

The use of probe As51 from repetitive DNA over the chromosomes, gotten by means of total DNA cut with the $K p n I$ restriction enzyme, within species from the complex A. scabripinnis, identified its association with the $18 \mathrm{~S}$ ribosomal DNA and the heterochromatic regions located in different autosomes and in the B chromosome [77]. These data reinforce previous hypotheses [78] about the possible intragenic origin of $\mathrm{B}$ chromosome in A. scabripinnis due to the formation of isochromosome in the standard complement. Actually, recent evidences corroborate B chromosome autopairing in the pachytene of meiotic cells in A. scabripinnis by applying FISH with As51 and WCP with B chromosome probe [14], gotten by microdissection and amplification by degenerate nucleotide primed and polymerase chain reaction (DOP-PCR) (Figure 5).

\section{Conclusions and Further Perspectives}

Fish might compose the biggest and most exciting challenge in the karyoevolutionary studies among vertebrates. No doubt that any other group rivals fish's huge biological diversity, which results from historically differentiated evolutionary processes that lead to their fascinating karyotype diversity. The diffusion of molecular biology tools provided 


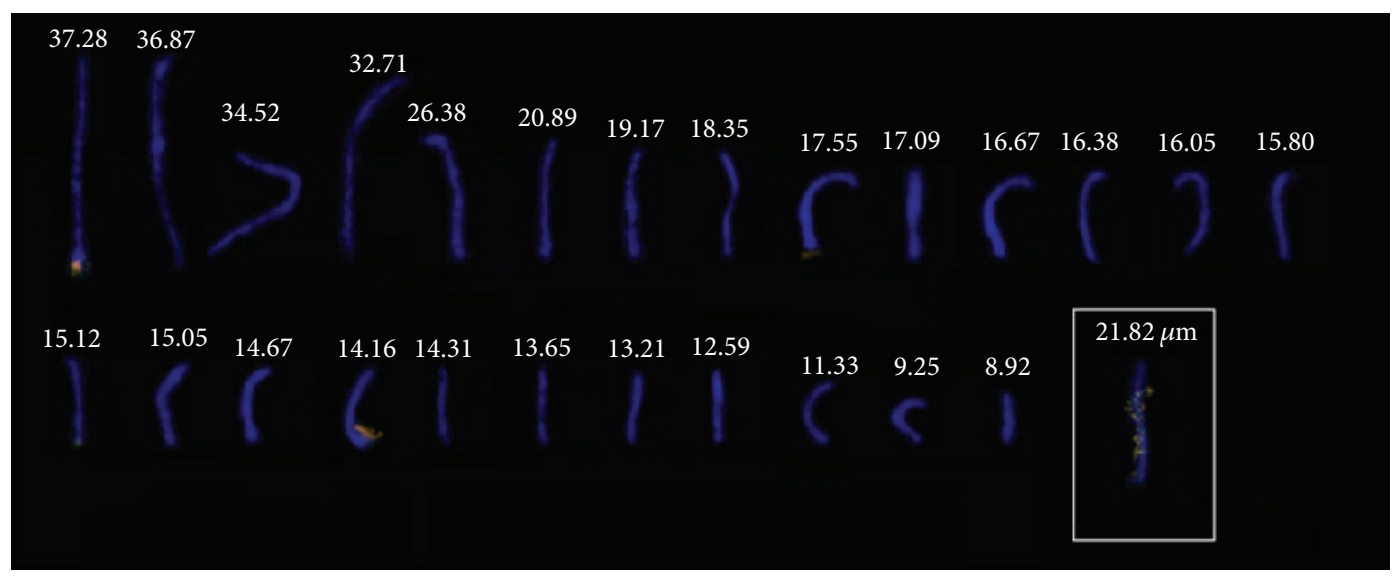

(a)

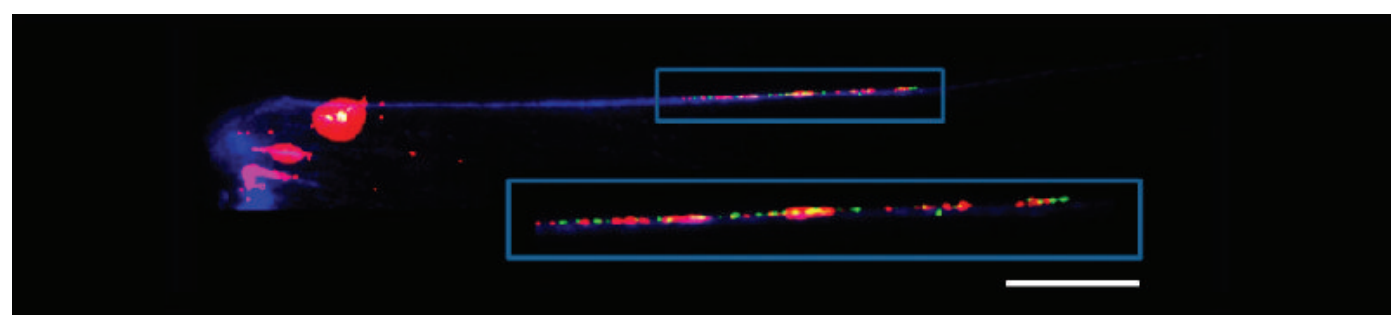

(b)

FIGURE 5: (a) Astyanax scabripinnis pachytene elements subjected to double FISH with $18 \mathrm{~S}$ ribosomal DNA probe (green) and those of the As51 repetitive sequence (red). These sequences are interspaced, showing syntenic and syntopic location, and present highlighted broad B chromosome distribution. The total length of each element is expressed in $\mu \mathrm{m}$. (b) Detail of the extended chromatin fiber subjected to double FISH showing the syntenic and syntopic colocation of $18 \mathrm{~S}$ and $A s 51$ sequences. Bar $=10 \mu \mathrm{m}$.

great advance to the chromosomal study in fish, in addition to the classic staining methodology and chromosomal banding. Thus, the fluorescent in situ hybridization (FISH) enables evolutionary analyses resulting from the location of moderately (e.g., 18S rDNA, 5S rDNA, and histones) and highly repetitive DNA sequences (satellite DNA, transposable elements, microsatellites, and heterochromatin) over the chromosomes.

Variations in the FISH procedure are rarely applied to fish. Such technical bottleneck affects the understanding of fish chromosome structure by restricting evolutionary inference possibilities since most of the species do not present clearly defined structural longitudinal bands (G-band and R-band).

This new cytogenetic field, called cytogenomics, is spreading due to its capacity to give resolute answers to countless questions nonaccessible by traditional methodologies. Indeed, the association of chromosomal loci with DNA sequencing and of biological diversity analysis methodologies with phylogenetics triggers the will to search for answers regarding evolutionary, taxonomic, and structural matters in fish. The most recent expectation lies in overcoming technical impairments regarding the use of FISH's varying techniques (WCP of euchromatic regions and mainly micro-FISH) as well as in the new integration with the up-to-date nextgeneration sequencing (NGS) techniques to be applied to this fantastic group of animals.

\section{Conflict of Interests}

The authors declare that there is no conflict of interests regarding the publication of this paper.

\section{References}

[1] J. G. Lundenberg, "The temporal context for diversification of Neotropical fishes," in Phylogeny and Classification of Neotropical Fishes, L. R. Malabarba, R. E. Reis, R. P. Vari et al., Eds., Edipucrs, Porto Alegre, Brazil, 1998.

[2] R. Van Der Laan, W. N. Eschmeyer, and R. Fricke, "Familygroup names of recent fishes," Zootaxa, vol. 3882, no. 1, p. 230, 2014.

[3] A. L. Dias and F. Foresti, "Cytogenetic studies on fishes of the family Pimelodidae (Siluroidei)," Revista Brasileira de Genética, vol. 16, no. 3, pp. 585-600, 1993.

[4] L. A. C. Bertollo, G. G. Born, J. A. Dergam, A. S. Fenocchio, and O. Moreira-Filho, "A biodiversity approach in the neotropical Erythrinidae fish, Hoplias malabaricus. Karyotypic survey, geographic distribution of cytotypes and cytotaxonomic considerations," Chromosome Research, vol. 8, no. 7, pp. 603613, 2000.

[5] U. P. Jacobina, E. Paiva, and J. A. Dergam, "Pleistocene karyotypic divergence in Hoplias malabaricus (Bloch, 1794) (Teleostei: Erythrinidae) populations in southeastern Brazil," Neotropical Ichthyology, vol. 9, no. 2, pp. 325-333, 2011. 
[6] E. Pizano, C. Ozouf-Costaz, F. Foresti, and B. G. Kapoor, Fish Cytogenetics, Science Publisher, Enfield, NH, USA, 2007.

[7] U. P. Jacobina, P. R. A. D. M. Affonso, P. L. S. Carneiro, and J. A. Dergam, "Biogeography and comparative cytogenetics between two populations of Hoplias malabaricus (Bloch, 1794) (Ostariophysi: Erythrinidae) from coastal basins in the State of Bahia, Brazil," Neotropical Ichthyology, vol. 7, no. 4, pp. 617-622, 2009.

[8] W. F. Molina, "Fish cytogenetics," in Chromosome Changes and Stasis in Marine Fish Groups, E. Pisano, C. Ozouf-Costa, F. Forest, and B. G. Kapoor, Eds., pp. 69-110, Science Publisher, Enfield, Conn, USA, 2007.

[9] M. Guerra, FISH-Conceitos e Aplicações na Citogenética, Sociedade Brasileira de Genética, 2004.

[10] R. S. Singh, J. Jiang, and B. S. Gill, "Current status and the future of fluorescence in situ hybridization (FISH) in plant genome research," Genome, vol. 49, no. 9, pp. 1057-1068, 2006.

[11] C. Martins, C. C. Mel, G. V. Targino, J. Mazzuchelli, and S. G. Oliveira, "Cytogenetic mapping and its contribution to the knowledge of animal genomes," in Advances in Genetics Research, K. V. Urbano, Ed., p. 82, Nova Science Publishers, New York, NY, USA, 2011.

[12] M. B. Cioff, C. Martins, L. Centofante, U. Jacobina, and L. A. C. Bertollo, "Chromosomal variability among allopatric populations of erythrinidae fish Hoplias malabaricus: mapping of three classes of repetitive DNAs," Cytogenetic and Genome Research, vol. 125, no. 2, pp. 132-141, 2009.

[13] D. R. Blanco, R. L. Lui, L. A. C. Bertollo, V. P. Margarido, and O. M. Filho, "Karyotypic diversity between allopatric populations of the group Hoplias malabaricus (Characiformes: Erythrinidae): evolutionary and biogeographic considerations," Neotropical Ichthyology, vol. 8, no. 2, pp. 361-368, 2010.

[14] M. R. Vicari, H. F. de Pistune Mello, J. P. Castro et al., "New insights on the origin of B chromosomes in Astyanax scabripinnis obtained by chromosome painting and FISH," Genetica, vol. 139, no. 8, pp. 1073-1081, 2011.

[15] C. F. Yano, J. Poltronieri, L. A. C. Bertollo, R. F. Artoni, T. Liehr, and M. de Bello Cioffi, "Chromosomal mapping of repetitive DNAs in Triportheus trifurcatus (Characidae, Characiformes): insights into the differentiation of the $\mathrm{Z}$ and $\mathrm{W}$ chromosomes," PLoS ONE, vol. 9, no. 3, Article ID e90946, 2014.

[16] M. Da Silva, D. A. Matoso, M. R. Vicari, M. C. De Almeida, V. P. Margarido, and R. F. Artoni, "Repetitive DNA and meiotic behavior of sex chromosomes in Gymnotus pantanal (Gymnotiformes, Gymnotidae)," Cytogenetic and Genome Research, vol. 135, no. 2, pp. 143-149, 2011.

[17] M. R. Vicari, V. Nogaroto, R. B. Noleto et al., "Satellite DNA and chromosomes in Neotropical fishes: methods, applications and perspectives," Journal of Fish Biology, vol. 76, no. 5, pp. 10941116, 2010.

[18] T. P. Miranda and A. C. Marques, "Abordagens atuais em biogeografia marinha," Revista da Biologia, vol. 7, pp. 41-48, 2011.

[19] J. S. Nelson, Fishes of the World, John Wiley \& Sons, New York, NY, USA, 2006.

[20] C. C. M. Neto, M. B. Cioffi, L. A. C. Bertollo, and W. F. Molina, "Molecular cytogenetic analysis of Haemulidae fish (Perciformes): evidence of evolutionary conservation," Journal of Experimental Marine Biology and Ecology, vol. 407, no. 1, pp. 97-100, 2011.
[21] P. M. Galetti Jr., C. T. Aguilar, and W. F. Molina, "An overview of marine fish cytogenetics," Hydrobiologia, vol. 420, no. 1-3, pp. 55-62, 2000.

[22] W. C. de Araújo, P. A. Martínez, and W. F. Molina, "Mapping of ribosomal DNA by FISH, EcoRI digestion and replication bands in the cardinalfish Apogon americanus (Perciformes)," Cytologia, vol. 75, no. 1, pp. 109-117, 2010.

[23] I. V. Accioly, L. A. C. Bertollo, G. W. W. F. Costa, U. P. Jacobina, and W. F. Molina, "Chromosomal population structuring in carangids (Perciformes) between the north-eastern and southeastern coasts of Brazil," African Journal of Marine Science, vol. 34, no. 3, pp. 383-389, 2012.

[24] U. P. Jacobina, P. A. Martinez, M. D. B. Cioffi, J. Garcia Jr., L. A. C. Bertollo, and W. F. Molina, "Morphological and karyotypic differentiation in Caranx lugubris (Perciformes: Carangidae) in the St. Peter and St. Paul Archipelago, mid-Atlantic Ridge," Helgoland Marine Research, vol. 68, no. 1, pp. 17-25, 2014.

[25] P. A. de Lima-Filho, M. de Bello Cioffi, L. A. C. Bertollo, and W. F. Molina, "Chromosomal and morphological divergences in Atlantic populations of the frillin goby Bathygobius soporator (Gobiidae, Perciformes)," Journal of Experimental Marine Biology and Ecology, vol. 434-435, pp. 63-70, 2012.

[26] J. E. Mank and J. C. Avise, "Phylogenetic conservation of chromosome numbers in Actinopterygiian fishes," Genetica, vol. 127, no. 1-3, pp. 321-327, 2006.

[27] L. L. Calado, L. A. C. Bertollo, M. B. Cioffi, G. W. W. F. Costa, U. P. Jacobina, and W. F. Molina, "Evolutionary dynamics of rDNA genes on chromosomes of the Eucinostomus fishes: cytotaxonomic and karyoevolutive implications," Genetics and Molecular Research, vol. 13, no. 4, pp. 9951-9959, 2014.

[28] L. L. Calado, L. A. C. Bertollo, G. W. W. F. D. Costa, and W. F. Molina, "Cytogenetic studies of Atlantic mojarras (Perciformes-Gerreidae): chromosomal mapping of 5S and $18 \mathrm{~S}$ ribosomal genes using double FISH," Aquaculture Research, vol. 44, no. 5, pp. 829-835, 2013.

[29] G. S. Myers, "Fresh-water fishes and the West Indian zoogeography," Annual Report of the Smithsonian Institution for 1937, 1938.

[30] R. E. Reis, O. S. Kullander, and C. J. J. Ferraris, Check List of the Freshwater Fishes of South and Central America, Edipucrs, Porto Alegre, Brazil, 2003.

[31] C. Oliveira, L. F. Almeida-Toledo, and F. Foresti, "Karyotypic evolution in Neotropical fishes," in Fish Cytogenetics, F. Foresti and G. B. Kapoor, Eds., pp. 111-164, Science Publisher, Enfield, NH, USA, 2007.

[32] M. C. S. L. Malabarba, "Revision of the Neotropical genus Triportheus cope, 1872 (Characiformes: Characidae)," Neotropical Ichthyology, vol. 2, no. 4, pp. 167-204, 2004.

[33] R. A. Torres, J. J. Roper, F. Foresti, and C. Oliveira, "Surprising genomic diversity in the Neotropical fish Synbranchus marmoratus (Teleostei: Synbranchidae): how many species?" Neotropical Ichthyology, vol. 3, pp. 277-284, 2005.

[34] T. L. Pereira, U. Santos, C. E. Schaefer et al., "Dispersal and vicariance of Hoplias malabaricus (Bloch, 1794) (Teleostei, Erythrinidae) populations of the Brazilian continental margin," Journal of Biogeography, vol. 40, no. 5, pp. 905-914, 2013.

[35] M. R. Vicari, R. F. Artoni, and L. A. C. Bertollo, "Comparative cytogenetics of Hoplias malabaricus (Pisces, Erythrinidae): a population analysis in adjacent hydrographic basins," Genetics and Molecular Biology, vol. 28, no. 1, pp. 103-110, 2005.

[36] E. Bellafronte, T. C. Mariguela, L. H. G. Pereira, C. Oliveira, and O. Moreira-Filho, "DNA barcode of Parodontidae species from 
the La Plata river basin - applying new data to clarify taxonomic problems," Neotropical Ichthyology, vol. 11, no. 3, pp. 497-506, 2013.

[37] E. Bellafronte, V. P. Margarido, and O. Moreira-Filho, "Cytotaxonomy of Parodon nasus and Parodon tortuosus (Pisces, Characiformes). A case of synonymy confirmed by cytogenetic analyses," Genetics and Molecular Biology, vol. 28, no. 4, pp. 710716, 2005.

[38] C. Martins and P. M. Galetti Jr., "Chromosomal localization of 5S rDNA genes in Leporinus fish (anostomidae, characiformes)," Chromosome Research, vol. 7, no. 5, pp. 363-367, 1999.

[39] L. C. De Barros, U. Santos, M. D. B. Cioffi, and J. A. Dergam, "Evolutionary divergence among Oligosarcus spp. (Ostariophysi, Characidae) from the São Francisco and Doce River Basins: Oligosarcus solitarius Menezes, 1987 shows the highest rates of chromosomal evolution in the Neotropical Region," Zebrafish, vol. 12, no. 1, pp. 102-110, 2015.

[40] C. C. M. Neto, P. A. Lima-Filho, W. C. Araújo, L. A. C. Bertollo, and W. F. Molina, "Differentiated evolutionary pathways in Haemulidae (Perciformes): karyotype stasis versus morphological differentiation," Reviews in Fish Biology and Fisheries, vol. 22, no. 2, pp. 457-465, 2012.

[41] W. F. Molina, P. A. Martinez, L. A. C. Bertollo, and C. J. Bidau, "Evidence for meiotic drive as an explanation for karyotype changes in fishes," Marine Genomics, vol. 15, pp. 29-34, 2014.

[42] G. W. W. F. Costa, Mapeamento físico de genes com fins biotecnológicos em peixes marinhos de interesse comercialrachycentridae e lutjanidae [Ph.D. thesis], Universidade Federal do Rio Grande do Norte, Natal, Brazil, 2015.

[43] M. J. I. Brum and P. M. Galetti Jr., "Teleostei ground plan karyotype," Journal of Comparative Biology, vol. 2, pp. 91-102, 1997.

[44] R. Arai, Fish Karyotypes: A Check List, Springer, Tokyo, Japan, 2011.

[45] E. Gornung, "Twenty years of physical mapping of major ribosomal RNA genes across the teleosts: a review of research," Cytogenetic and Genome Research, vol. 141, no. 2-3, pp. 90-102, 2013.

[46] C. Martins, "Chromosomes and repetitive DNAs: a contribution to the knowledge of fish genome," in Fish Cytogenetics, E. Pisano, C. Ozouf-Costaz, F. Foresti, and G. B. Kapoor, Eds., pp. 421-453, Science Publisher, Enfield, NH, USA, 2007.

[47] D. Campo and E. García-Vázquez, "Evolution in the block: common elements of $5 \mathrm{~S}$ rDNA organization and evolutionary patterns in distant fish genera," Genome, vol. 55, no. 1, pp. 3344, 2012.

[48] L. Rebordinos, I. Cross, and A. Merlo, "High evolutionary dynamism in 5S rDNA of fish: state of the art," Cytogenetic and Genome Research, vol. 141, no. 2-3, pp. 103-113, 2013.

[49] P. R. A. D. M. Affonso, M. A. Fernandes, J. S. Almeida, and W. F. Molina, "Sequential steps of chromosomal differentiation in Atlantic surgeonfishes: evolutionary inferences," The Scientific World Journal, vol. 2014, Article ID 825703, 7 pages, 2014.

[50] G. W. W. F. Costa, M. B. Cioffi, L. A. C. Bertollo, and W. F. Molina, "Unusual dispersion of histone repeats on the whole chromosomal complement and their colocalization with ribosomal genes in Rachycentron canadum (Rachycentridae, Perciformes)," Cytogenetic and Genome Research, vol. 144, no. 1, pp. 62-67, 2014.

[51] M. Nirchio, J. I. Gaviria, C. Oliveira, I. A. Ferreira, and C. Martins, "Cytogenetic analysis of three species of the genus
Haemulon (Teleostei: Haemulinae) from Margarita Island, Venezuela," Genetica, vol. 131, no. 2, pp. 135-140, 2007.

[52] Y.-I. Matsumoto, H. Yasuda, M.-A. Yamada, S. Mita, and T. Marunouchi, "Evidence for the involvement of $\mathrm{Hl}$ histone phosphorylation in chromosome condensation," Nature, vol. 284, no. 5752, pp. 181-183, 1980.

[53] J. R. Davie and G. P. Delcuve, "Characterization and chromatin distribution of the $\mathrm{H} 1$ histones and high-mobility-group nonhistone chromosomal proteins of trout liver and hepatocellular carcinoma," The Biochemical Journal, vol. 280, no. 2, pp. 491-497, 1991.

[54] T. Hankeln and E. R. Schmidt, "Divergent evolution of an 'orphon' histone gene cluster in Chironomus," Journal of Molecular Biology, vol. 234, no. 4, pp. 1301-1307, 1993.

[55] J. M. Eirín-López, A. M. González-Tizón, A. Martínez, and J. Méndez, "Birth-and-death evolution with strong purifying selection in the histone $\mathrm{H} 1$ multigene family and the origin of orphon $\mathrm{H} 2$ genes," Molecular Biology and Evolution, vol. 21, no. 10, pp. 1992-2003, 2004.

[56] T. A. Voltolin, A. Laudicina, J. A. Senhorini et al., "Origin and molecular organization of supernumerary chromosomes of Prochilodus lineatus (Characiformes, Prochilodontidae) obtained by DNA probes," Genetica, vol. 138, no. 11, pp. 1133-1139, 2010.

[57] M. G. Kidwell, "Transposable elements and the evolution of genome size in eukaryotes," Genetica, vol. 115, no. 1, pp. 49-63, 2002.

[58] A. B. Poletto, I. A. Ferreira, and C. Martins, "The B chromosomes of the African cichlid fish Haplochromis obliquidens harbour 18S rRNA gene copies," BMC Genetics, vol. 11, article 1, 2010.

[59] M. B. Cioffi, J. P. M. Camacho, and L. A. C. Bertollo, "Repetitive DNAs and differentiation of sex chromosomes in neotropical fishes," Cytogenetic and Genome Research, vol. 132, no. 3, pp. 188-194, 2011.

[60] P. M. Galetti Jr., C. A. Mestriner, P. J. Monaco, and E. M. Rasch, "Post-zygotic modifications and intra- and interindividual nucleolar organizing region variations in fish: report of a case involving Leporinus friderici," Chromosome Research, vol. 3, no. 5, pp. 285-290, 1995.

[61] O. Moreira-Filho and L. A. C. Bertollo, "Cytosystematics and cytogenetics distribution of sex chromosome mechanisms in neotropical fish and description of a ZZ/ZW system in Parodon hilarii (Parodontidae)," Caryologia, vol. 46, pp. 37-41, 1993.

[62] R. F. Artoni and L. A. C. Bertollo, "Evolutionary aspects of the ZZ/ZW sex chromosome system in the Characidae fish, genus Triportheus. A monophyletic state and NOR location on the W chromosome," Heredity, vol. 89, no. 1, pp. 15-19, 2002.

[63] A. A. Andreata, L. F. Almeida-Toledo, C. Oliveira, and S. A. Toledo-Filho, "Chromosome studies in Hypoptopomatinae (Pisces, Siluriformes, Loricariidae): I. XX/XY sex chromosome heteromorphism in Pseudotocinclus tietensis," Cytologia, vol. 57, pp. 369-372, 1992.

[64] O. M. Filho, L. A. C. Bertollo, and P. M. Junior Jr., "Evidences for a multiple sex chromosome system with female heterogamety in Apareiodon affinis (Pisces, Parodontidae)," Caryologia, vol. 33, no. 1, pp. 83-91, 1980.

[65] L. A. C. Bertollo, M. S. Fontes, A. S. Fenocchio, and J. Cano, "The $\mathrm{X} 1 \mathrm{X} 2 \mathrm{Y}$ sex chromosome system in the fish Hoplias malabaricus. I. G-, C- and chromosome replication banding," Chromosome Research, vol. 5, no. 7, pp. 493-499, 1997. 
[66] L. F. Almeida-Toledo, F. Foresti, M. F. Z. Daniel, and S. A. Toledo-Filho, "Sex chromosome evolution in fish: the formation of the neo-Y chromosome in Eigenmannia (Gymnotiformes)," Chromosoma, vol. 109, no. 3, pp. 197-200, 2000.

[67] D. Diniz, A. Laudicina, M. B. Cioffi, and L. A. C. Bertollo, "Microdissection and whole chromosome painting. Improving sex chromosome analysis in Triportheus (Teleostei, Characiformes)," Cytogenetic and Genome Research, vol. 122, no. 2, pp. 163-168, 2008.

[68] D. R. Blanco, M. R. Vicari, R. L. Lui et al., "Origin of the $\mathrm{X}_{1} \mathrm{X}_{1} \mathrm{X}_{2} \mathrm{X}_{2} / \mathrm{X}_{1} \mathrm{X}_{2} \mathrm{Y}$ sex chromosome system of Harttia punctata (Siluriformes, Loricariidae) inferred from chromosome painting and FISH with ribosomal DNA markers," Genetica, vol. 142, no. 2, pp. 119-126, 2014.

[69] M. L. Terencio, C. H. Schneider, M. C. Gross et al., "Repetitive sequences associated with differentiation of $\mathrm{W}$ chromosome in Semaprochilodus taeniurus," Genetica, vol. 140, no. 10-12, pp. 505-512, 2012.

[70] J. N. Falcão, O. Moreira-Filho, and L. A. C. Bertollo, "An additional chromosome in two fish species," Revista Brasileira de Genetica, vol. 7, no. 1, pp. 109-118, 1984.

[71] E. Pauls and L. A. C. Bertollo, "Distribution of a supernumerary chromosome system and aspects of karyotypic evolution in the genus Prochilodus (Pisces, Prochilodontidae)," Genetica, vol. 81, no. 2, pp. 117-123, 1990.

[72] P. C. Venere and P. M. Galetti, "Natural triploidy and chromosome B in the fish Curimata modesta (Curimatidae, Characiformes)," Revista Brasileira de Genetica, vol. 18, pp. 681-687, 1985.

[73] C. Oliveira and F. Foresti, "Occurrence of supranumerary microchromosomes in Steindachnerina insculpta (Pisces, Characiformes, Curimatidae)," Cytobios, vol. 76, pp. 183-186, 1993.

[74] M. C. Pastori, A. S. Fenocchio, and P. A. López, "First description of microchromosome in the anostomidae fish Schizodon nasutus from Argentina," Brazilian Journal of Genetics, vol. 20, no. 3, pp. 425-427, 1997.

[75] J. P. M. Camacho, T. F. Sharbel, and L. W. Beukeboom, "Bchromosome evolution," Philosophical Transactions of the Royal Society B: Biological Sciences, vol. 355, no. 1394, pp. 163-178, 2000.

[76] O. Moreira-Filho, P. M. Galetti Jr., and L. A. C. Bertollo, "B chromosomes in the fish Astyanax scabripinnis (Characidae, Tetragonopterinae): an overview in natural populations," Cytogenetic and Genome Research, vol. 106, no. 2-4, pp. 230-234, 2004.

[77] C. A. Mestriner, P. M. Galetti Jr., S. R. Valentini et al., "Structural and functional evidence that a B chromosome in the characid fish Astyanax scabripinnis is an isochromosome," Heredity, vol. 85, no. 1, pp. 1-9, 2000.

[78] V. E. Vicente, O. Moreira-Filho, and J. P. M. Camacho, "Sex-ratio distortion associated with the presence of a B chromosome in Astyanax scabripinnis (Teleostei, Characidae)," Cytogenetics and Cell Genetics, vol. 74, no. 1-2, pp. 70-75, 1996. 

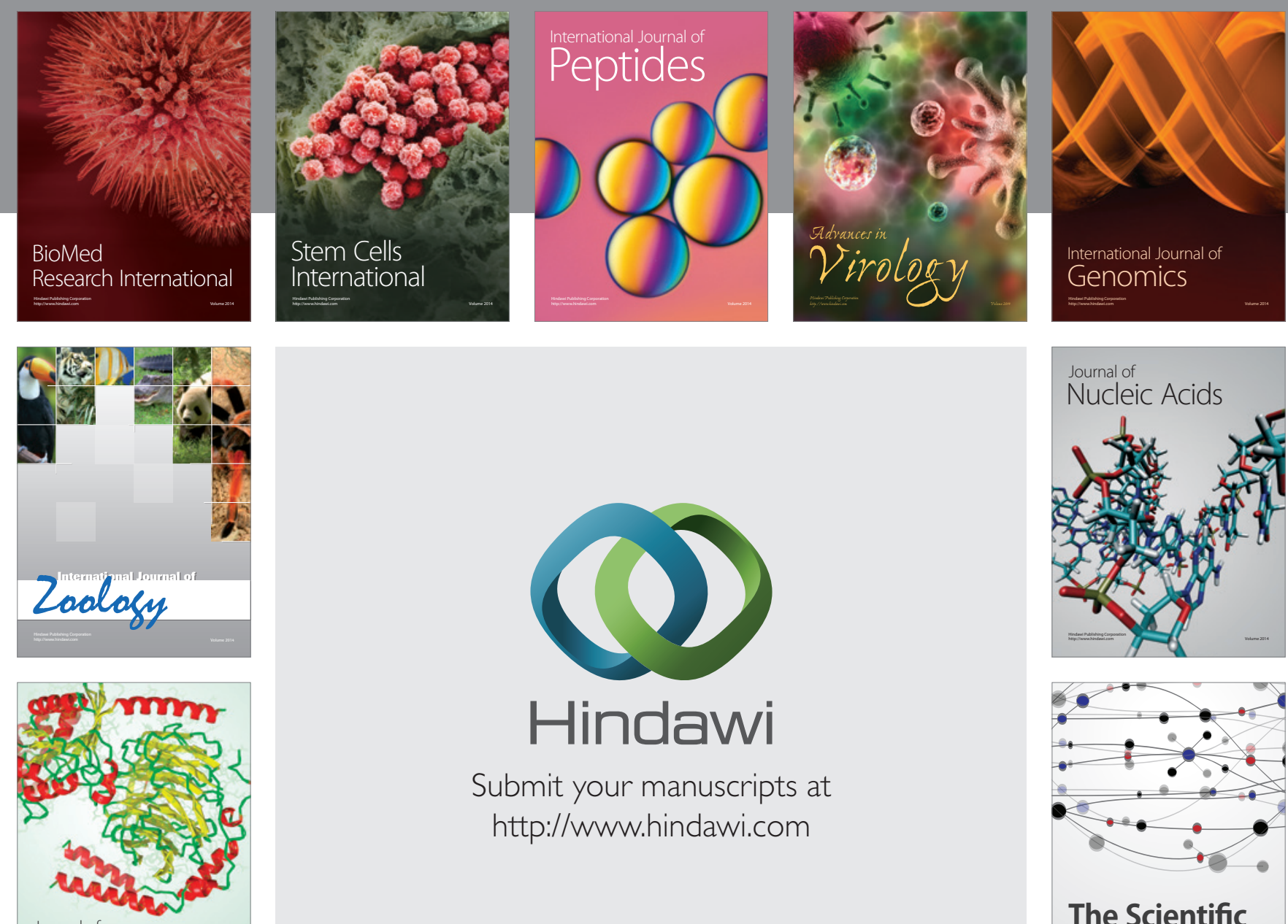

Submit your manuscripts at

http://www.hindawi.com

Journal of
Signal Transduction
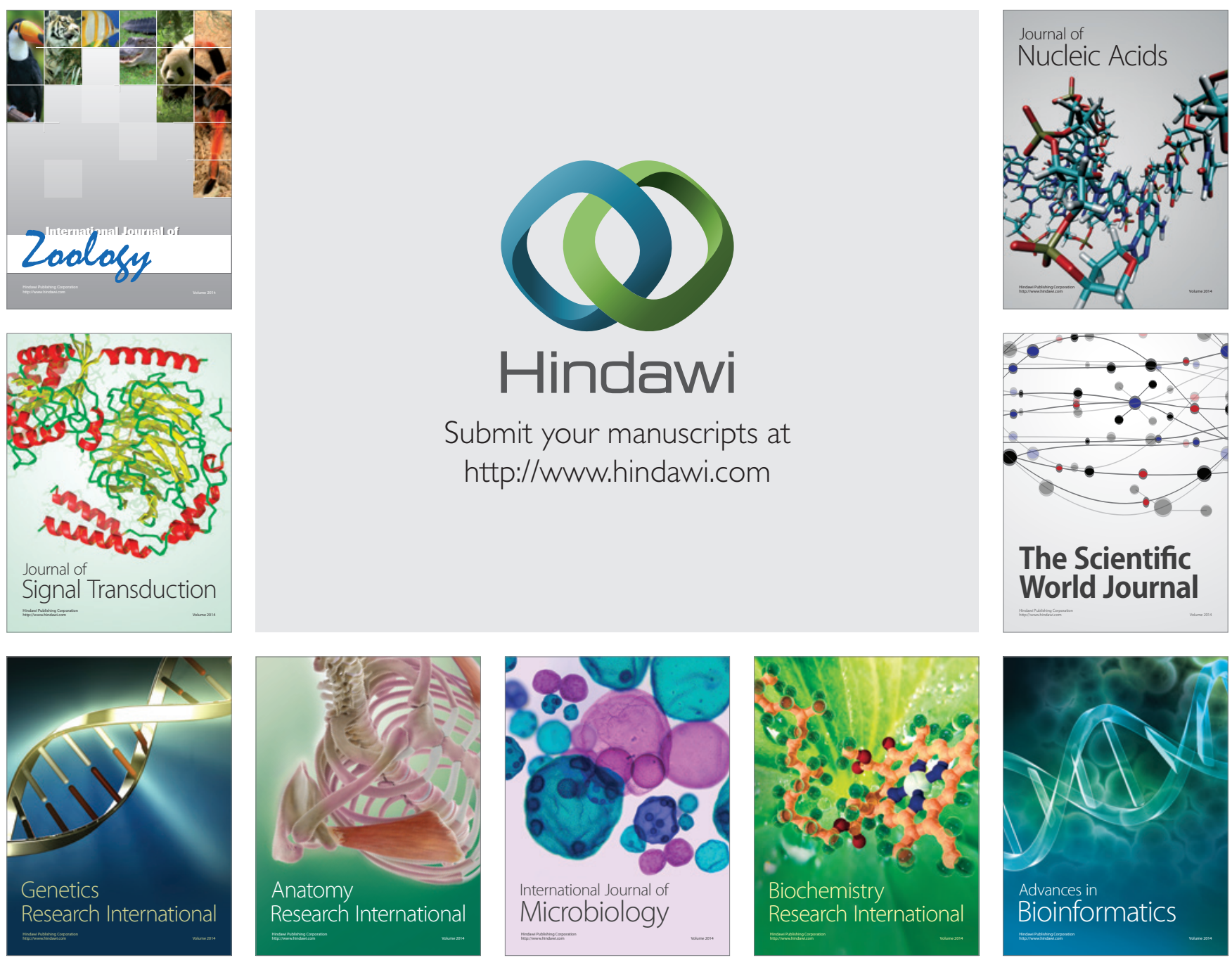

The Scientific World Journal
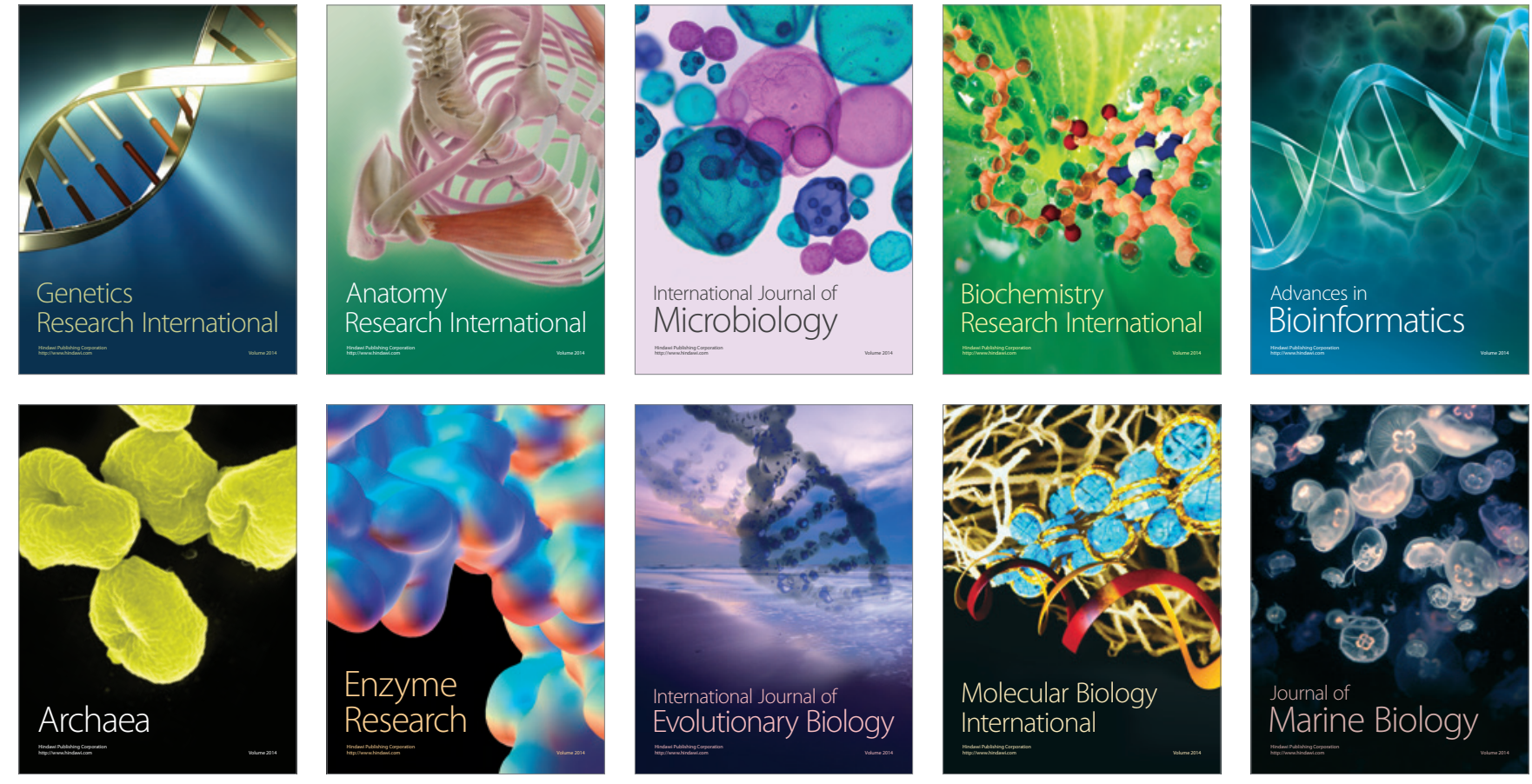